\title{
MARKUS LIPOWICZ
}

(Kraków)

\section{IDEA SPRAWIEDLIWOŚCI W MYŚLI KAROLA MARKSA}

\begin{abstract}
Wstęp
W dziejach kultury europejskiej można znaleźć kilka kluczowych idei i pojęć, które w sposób szczególny wpłynęły na kulturę zachodniej cywilizacji. Są to niewątpliwie idee piękna, prawdy, miłości, śmierci, wojny, władzy, sprawiedliwości, wolności, pracy i szczęścia. To właśnie te idee w sposób szczególny towarzyszyły bądź wpływały na rozwój kultury i dziejów cywilizacji Europy. Także współczesne kontrowersje wokół tychże idei i pojęć stanowią znaczącą część konfliktów publicznych i sporów naukowych. Dlatego też nie sposób sobie wyobrazić odłączenia Europy od swoich intelektualnych korzeni. Dopiero rzetelna analiza i interpretacja tych kluczowych idei umożliwia zrozumienie specyfiki i wyjątkowości zachodniej cywilizacji. Szczególnie w czasach integracji europejskiej i towarzyszaccym jej konfliktom normatywnym warto przypomnieć postulat epoki Oświecenia, że rozwój intelektualny stanowi aksjologiczną podstawę dla nowoczesnej cywilizacji. Ważną częścia tego rozwoju intelektualnego jest między innymi krytyczna refleksja nad tymi ideami, które nie tylko ukształtowały naszą zbiorową tożsamość w przeszłości, ale które dostarczają nam tych treści myślowych, które z kolei umożliwiają nam tworzenie nowych perspektyw rozwoju naszej cywilizacji - Europy. W niniejszym artykule tematem i zarazem problemem badawczym będzie jedno z tych wielkich pojęć - sprawiedliwość. Nie zamierzam oczywiście w sposób syntetyczny streścić i przeanalizować wszystkich ideowych odmian tego pojęcia. Zamierzam tutaj jedynie w sposób skrótowy przeanalizować oraz zinterpretować bardzo osobliwe podejście do idei sprawiedliwości Karola Marksa.

Zdaniem Jana Błuszkowskiego Marks sformułował „,teorię rozwoju społecznego, która stała się instrumentem kształtowania sprawiedliwych stosunków spo-
\end{abstract}


łecznych, teorię pozwalającą świadomie wpływać na egzystencję ludzką" ${ }^{1}$. Niewątpliwie Marks był po Tomaszu Morusie i Janie Jakubie Rousseau pierwszym powszechnie rozpoznawalnym myślicielem, który z problematyki „społecznej”, czyli z ekonomicznych nierówności oraz biedy uczynił centralny aspekt całej swojej twórczości ${ }^{2}$. Jednocześnie Marks niezwykle rzadko odnosił się wprost do idei sprawiedliwości jako takiej - a gdy to czynił, to raczej w sposób zdystansowany i krytyczny, jak choćby w słynnej Krytyce Programu Gotajskiego ${ }^{3}$. Albowiem zgodnie z jego materialistycznym tokiem rozumowania „sprawiedliwość” była jedynie kolejną ideą, która maskowała realne procesy społeczne i legitymizowała tymczasowe formy wyzysku. Jak ten paradoks tłumaczyć?

Otóż spróbuję - opierając się głównie na myśli niemarksisty Ralfa Dahrendorfa $^{4}$ - wykazać, iż Marks znał dwa pojęcia sprawiedliwości: jedno relatywne, a drugie absolutne. Relacja między tymi dwoma odmianami jest bardzo osobliwa: o ile samo stosowanie relatywnego pojęcia sprawiedliwości było przedmiotem bezwzględnej krytyki Marksa, o tyle absolutne pojęcie sprawiedliwości stanowi niewypowiedziane centrum jego wielowątkowej twórczości. Z perspektywy analizy idei sprawiedliwości myśl Marksa upodabnia się do słynnego Traktatu logiczno-filozoficznego Ludwiga Wittgensteina. Marks wydaje się świadomie milczeć o tym, co zgodnie z jego własnym ruchem myślowym powinno być uznane za najważniejsze, a jednocześnie czego w sposób bezpośredni wyrazić się nie da. Podobnie jak Wittgenstein w swojej wczesnej twórczości zdecydował się uhonorować kluczowe dla egzystencji ludzkiej idee milczeniem ${ }^{5}$, tak również Marks nie zamierzał uczynić z fundamentalnej problematyki, jakim niewątpliwie jest zagadnienie sprawiedliwości społecznej, pustego „frazesu”. Był on raczej przekonany, że analiza rozwoju materialnych warunków życia społecznego rozwiąże ów filozoficzny problem w sposób samorzutny, praktyczny - rewolucyjny. Marks w wyraził możliwie najbardziej radykalną postawę wobec kwestii sprawiedliwości społecznej. Z jego punktu widzenia tylko realne efekty rewolucji społecznej moga zostać uznane jako sprawiedliwe. Dopóki te nie zostaną osiągnięte, dopóty nie ma nawet możliwości mówienia o sprawiedliwości - a „o czym nie można mówić, o tym trzeba milczeć" 6 .

1 J. Błuszkowski, Wstęp, w: K. Marks, Myśli, J. Błuszkowski, A. Wajda (red.), Warszawa 1978, s. 5.

2 Por. T. Ebert, Soziale Gerechtigkeit. Ideen - Geschichte - Kontroversen, Bonn 2010, s. 161.

3 Por. K. Marks, Krytyka Programu Gotajskiego (Fragmenty), w: tenże, Pisma wybrane. Cztowiek $i$ socjalizm, wyboru dokonał i wstępem opatrzył J. Ładyka, Warszawa 1979.

4 R. Dahrendorf, Die Idee des Gerechten im Denken von Karl Marx, Hannover 1971.

5 Por. H. Tetens, Wittgensteins „Tractatus”. Ein Kommentar, Stuttgart 2009.

6 L. Wittgenstein, Tractatus logico-philosophicus, przeł. B. Wolniewicz, Kraków 1970, s. 88 (zdanie 7). 


\section{Relatywna idea sprawiedliwości Marksa}

Jak już zaznaczyłem we wstępie: kiedy zaczynamy rozważać Marksowską ideę sprawiedliwości, to już na samym początku natrafiamy na dziwny paradoks: z jednej strony pisma Marksa wydają się być przepełnione namiętnym protestem przeciwko biedzie, wyzyskowi i niesprawiedliwości, co w XIX i XX wieku zainspirowało całą rzeszę intelektualistów, polityków, działaczy społecznych i naukowców, z drugiej Marks niezwykle rzadko stosował samo pojęcie sprawiedliwości. A kiedy już pisał bezpośrednio o tej problematyce, to zazwyczaj podkreślał jej błahość ${ }^{7}$. Mamy więc do czynienia z twórczością człowieka, który wydaje się nawoływać obywateli do tego, aby zrzucili kajdany niesprawiedliwego porządku społecznego unikając jednak sformułowania koncepcji sprawiedliwego podziału dóbr ${ }^{8}$. Przypadek?

Paradoks ten tłumaczyć można w sposób następujący: w odróżnieniu od wielu innych myślicieli i działaczy społecznych, Marks nie dostrzegał w programie komunistycznym roszczenia etyczno-moralnego. Warto sobie uświadomić, iz Marks nie zarzucał kapitalizmowi „niesprawiedliwości”, lecz atestował temu systemowi autodestrukcyjną skłonność do upadku ze względu na wewnętrzne „sprzeczności” 9. Nie był on także utopistą, który w imię wizji „lepszej przyszłości” krytykował ówczesne relacje społeczne. Marks usiłował zastąpić utopijny socjalizm naukową refleksją nad logiką dziejów. Próbował on raczej w sposób czysto racjonalny dowieść, że uspołecznienie środków produkcji stanowi konieczny wynik dziejów - że rozpad kapitalizmu stanowi konieczny efekt samego rozwoju kapitalizmu. Nic więc dziwnego, że Marks swoją krytykę wolnorynkowych stosunków społecznych nie ubrał w język moralizujący. Dlatego już sama idea sprawiedliwości społecznej wydawała się Marksowi wysoce podejrzana: służyła ona jego zdaniem niemal zawsze do legitymizacji panujących stosunków społecznych - tak, aby klasa panująca mogła usprawiedliwiać swoją władzę na poziomie prawnym, politycznym, religijnym, artystycznym a nawet filozoficznym ${ }^{10}$. „Cóż to jest «sprawiedliwy podział»? - pyta Marks - Czyż burżuazja nie zapewnia, że dzisiejszy podział jest «sprawiedliwy»? I czyż istotnie nie jest on jedynym «sprawiedliwym» podziałem na gruncie dzisiejszego sposobu produkcji?" 11.

Dochodzimy tutaj do bardzo ważnego i podstawowego problemu Marksowskiej myśli społecznej: otóż w opozycji do heglowskiej i młodoheglowskiej tradycji myślowej Marks wykluczał sprawczą rolę idei w kształtowaniu dziejów porządku

\footnotetext{
7 Por. T. Ebert, dz. cyt., s. 162.

8 R. Dahrendorf, dz. cyt., s. 15.

9 Por. T. Ebert, dz. cyt., s. 162.

10 E. Holzleithner, Gerechtigkeit, Stuttgart 2009, s. 35.

11 K. Marks, Krytyka Programu Gotajskiego, wyd. cyt., s. 739.
} 
społecznego. Tym samym w sposób jednoznaczny odcinał się od stanowiska, jakoby życie ludzkie było określone przez świadomość, czyli poprzez treści myślowe wyrażone w pojęciach ${ }^{12}$. To, w jaki sposób ludzie danej zbiorowości kształtują swoje życie społeczne, „zależy od materialnych warunków ich produkcji” ${ }^{13}$, a nie od ich (mniej lub bardziej skrzywionych bądź wprost fałszywych) wyobrażeń na ten temat. Idee to najczęściej „złudzenia świadomości”, czyli nieudane próby refleksyjnego odtworzenia realnych podstaw życia społecznego bazujących na interesie klasowym ${ }^{14}$. Sprawczą rolę w dziejach ludzkości odgrywały według Marksa zawsze zarówno siły jak i towarzyszace im stosunki produkcji. Warto w celu uniknięcia nieporozumienia dodać, iż Marks bynajmniej nie postulował, jakoby stosunki produkcji były rzeczami materialnymi pozbawionymi ideowej struktury. Twierdził on raczej, że relacje międzyludzkie, stosunki władzy i panowania, czyli cała rzeczywistość społeczna, w której jednostki żyją i pracują, określa stan umysłu jednostek ${ }^{15}$. Miejscem powstania idei nie jest zatem rozum jednostki, lecz sposób funkcjonowania rozumu stanowi wypadkową siłę życia społecznego.

Niechęć Marksa do atakowania systemu kapitalistycznego w imię abstrakcyjnej idei sprawiedliwości opartej na czysto rozumowych spekulacjach niezwykle utrudnia zrozumienie aksjologicznego wymiaru jego dzieła. Można mieć nawet wątpliwości czy w kontekście dzieła Marksowskiego w ogóle można w sposób sensowny mówić o idei sprawiedliwości. Niemiecka tradycja myślowa przypisywała idei ponadczasową „obiektywną egzystencję” czyniącą z poszczególnego człowieka jedynie nośnik poszczególnej treści myślowej ${ }^{16}$. Także Proudhonowi w ostrym tonie zarzucał Marks, że w jego myśleniu „człowiek jest tylko narzędziem, którym idea [...] posługuje się w celu własnego rozwoju" ${ }^{17}$. Według powszechnej interpretacji Marksa zredukował on ontologiczny status idei do bycia fenomenami wtórnymi do interesów ekonomicznych oraz stosunków panowania grup społecznych ${ }^{18}$. Ten sposób myślenia, zwany „materializmem historycznym”, budził i nadal budzi kontrowersje i powoduje nieporozumienie, jakoby Marks gardził całym światem intelektu i rozumu. Dlatego również tutaj warto zaznaczyć, iż proklamowana przez Marksa wtórność idei w stosunku do faktycznej rzeczywistości społecznej nie oznaczała, iż traktował on idee jako bezwartościowe dodatki, epifenomeny bądź

12 Por. R. Dahrendorf, dz. cyt., s. 41, 44.

13 K. Marks, Ideologia niemiecka (Fragmenty), w: tenże, Pisma wybrane, wyd. cyt., s. 236.

14 Por. tamże, s. 234.

15 Por. R. Dahrendorf, dz. cyt., s. 46.

16 Por. B. Stollberg-Rilinger, Einleitung. Was heißt Ideengeschichte?, w: Ideengeschichte. Basistexte, B. Stollberg-Rollinger (red.), Stuttgart 2010, s. 13.

17 K. Marks, List Marksa do Pawla Annienkowa w Paryżu, w: tenże, Pisma wybrane, wyd. cyt., s. 767.

18 Por. B. Stollberg-Rilinger, dz. cyt., s. 17. 
mechanicznie zdeterminowane odruchy realnych stosunków społecznych ${ }^{19}$. Marks przyznawał, że splatając się „z materialną działalnością ludzi i ich materialnymi stosunkami wewnętrznymi” idee stanowią ,język rzeczywistego życia” ${ }^{20}$. Marks nie stwierdza miałkości idei, lecz to, że nie mają one niezależnego wobec rzeczywistości społecznej bytu, że świadomość ludzka jest określona przez zbiorowy kontekst życia i pracy. Idee same z siebie niczego nie tworzą, lecz stanowią produkt ludzi działających w kontekście faktycznego życia społecznego uwarunkowanego przez rozwój gospodarczy ${ }^{21}$. Pojęcia nie wyrażają zdaniem Marksa abstrakcyjnych idei, lecz to same idee w krzywym zwierciadle obrazują rzeczywiste stosunki produkcji, czyli materialne podstawy życia społecznego. Właśnie z tego powodu idee powinny stać się przedmiotem krytyki - ale nie za pomocą i z perspektywy innych, konkurencyjnych idei. Zamiast w sposób doktrynerski wprowadzać nowe zasady, reforma świadomości w duchu Marksa powinna polegać na tym, „żeby świat spostrzegał swą własną świadomość, [...] żeby mu wyjaśnić własną jego działalność” 22. Zdanie Marksa, iż „krytyka religii stanowi przesłankę wszelkiej krytyki" ${ }^{23}$, trzeba widzieć w kontekście szerokim: chodzi o krytykę całej ideowej struktury życia ludzkiego - tak, aby człowiek mógł pojąć, że to on poprzez relacje z innymi ludźmi stwarza treści myślowe, a nie one jego. Walka przeciwko ideom jest pośrednią walką przeciwko dynamice życia społecznego, które przez owe idee wyraża swój własny byt ${ }^{24}$. W ten oto właśnie sposób krytyka idei staje się krytyką realnych stosunków społecznych 25 .

To, co tyczy się wszystkich idei, dotyczy rzecz jasna także idei sprawiedliwości: struktura relacji społecznych określa i pobudza wyobraźnię wobec tego, co jest przez większość ludzi żyjących w danej zbiorowości uznawane za sprawiedliwe ${ }^{26}$. Idea sprawiedliwości nie wyraża jednak marzeń poszczególnych jednostek, lecz stanowi derywat rzeczywistych stosunków społecznych. Ten aspekt właśnie różni myśl Marksa od większości innych teoretyków i myślicieli społecznych: o ile idee sprawiedliwości Platona, Arystotelesa, św. Tomasza czy Kanta wydają się wynikać z czystej myśli, rozumu, o tyle u Marksa idea sprawiedliwości wydaje się być zawsze sprzężona z faktycznym życiem społecznym.

19 Por. R. Dahrendorf, dz. cyt., s. 47.

20 K. Marks, Ideologia niemiecka, wyd. cyt., s. 243.

21 Tamże, s. 244.

22 K. Marks, Marks do Rugego, w: tenże, Pisma wybrane, wyd. cyt., s. 28.

23 Por. K. Marks, Przyczynek do krytyki Heglowskiej filozofii prawa. Wstęp, w: tenże, Pisma wybrane, wyd. cyt., s. 30.

24 Por. tamże.

25 Por. tamże, s. 31.

26 Por. R. Dahrendorf, dz. cyt., s. 50. 
Z powyższego wynika coś niezwykle ciekawego: Marks był na poziomie ideowym bezkompromisowym relatywistą ${ }^{27}$. Każda jakościowa zmiana sił wytwórczych „pociąga za sobą nowe formy podziału pracy” ${ }^{28}$, którym towarzyszą nowe treści myślowe w postaci idei. Każdy system ma zatem „swoje” treści myślowe wywodzące się z poprzednich systemów. W przypadku idei sprawiedliwości mamy zatem do czynienia z ideą „zgodności z systemem” 29, czyli tymczasową formą ekonomiczną. O prawie Marks stwierdził, że nigdy nie może ono „być wyższe niż ustrój ekonomiczny i uwarunkowany przezeń rozwój kulturalny społeczeństwa" ${ }^{30}$. Wszystko wskazuje na to, że Marks bardzo podobnie myślał o statusie idei sprawiedliwości społecznej. Paradoksalnie w tym punkcie myśl jego była dużo bliższa przedstawicielom klasycznego liberalizmu aniżeli myślom ówczesnych mu socjalistów - „socjalistycznych sekciarzy”, jak zwykł się pogardliwie o nich wyrażać ${ }^{31}$. Zgadzał się on z ekonomistami, iż gospodarka działa według własnych zasad i że w obrębie tychże zasad wszelkie roszczenia wychodzące ponad zasadę wolnego rynku są pozbawione sensu. Sprawiedliwość zawsze jest „w” samym społeczeństwie - a nie poza nim ${ }^{32}$. W dotychczasowej dynamice dziejów nie sposób zatem według Marksa odnaleźć punktu Archimedesowego, dzięki któremu można by w sposób niezależny sformułować uniwersalnie obowiązujące normatywne standardy życia społecznego. Ponadto próba abstrakcji od rzeczywistych form życia społecznego jest czystą metafizyką, spekulacją przekraczającą granice myślenia naukowego. Każdy sposób produkcji wytwarza swoje własne zasady sprawiedliwości. Ta „sprawiedliwość” oparta na nierównej dystrybucji dóbr oraz pracy najemnej jest w ramach kapitalistycznego systemu jak najbardziej sprawiedliwa bo zgodna z systemem ${ }^{33}$. Idee sprawiedliwości ze wcześniejszych okresów dziejowych co prawda wciąż istnieją, ale straciły na poziomie instytucjonalnym swój obowiązujący charakter - stały się „czystymi myślami” ${ }^{34}$. Dlatego Marks wszelkie roszczenia w imię jakiejkolwiek abstrakcyjnej idei sprawiedliwości, która w swojej treści wychodziłaby poza tymczasowe zasady życia społecznego, traktował jako „frazesy” zwalczające inne - „frazesy” 35.

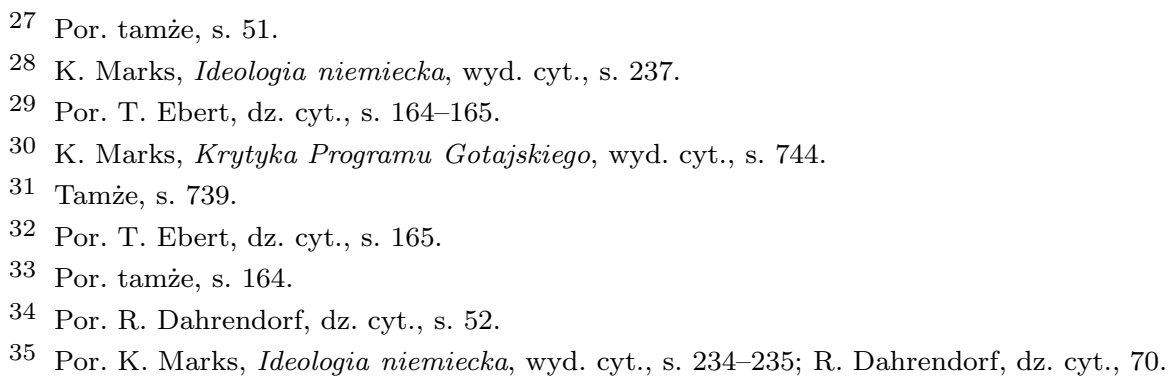


Marks więc niewątpliwie znał, pojmował i polemizował z relatywna ideą sprawiedliwości. Jednocześnie - i tu się już kończy relatywizm Marksa - nie godził się na takie pojęcie sprawiedliwości, gdyż pogardzał on wręcz staraniami socjalistów, aby w imię „przestarzałych frazesów” narzucać ruchowi socjalistycznemu wyobrażenia wywodzące się z systemów opartych na wyzysku ${ }^{36}$. Ta krytyka „socjalistycznych sekciarzy" wydaje się wskazywać, iż Marks miał jeszcze dodatkowe wyobrażenie sprawiedliwości wychodzące ponad systemowe ograniczenia, któremu świadomie w swoich głównych pismach nie dał bezpośredniego wyrazu. Niemniej w roku 1872 Marks na cześć ruchu Międzynarodowego Stowarzyszenia Robotników wygłosił takie oto zdanie: „Zważywszy, [...] że ekonomiczne podporządkowanie człowieka pracy monopoliście środków pracy [...] stanowi podstawę niewolnictwa we wszelkich jego formach, podstawę wszelkiej nędzy społecznej, degradacji umysłowej i zależności politycznej, [...] założone zostało Międzynarodowe Stowarzyszenie Robotników. Oświadcza ono: że wszelkie wstępujące doń stowarzyszenia i poszczególne osoby będą wyznawać prawde, sprawiedliwość i moralność za podstawę postępowania wobec siebie nawzajem oraz wobec wszystkich ludzi, niezależnie od koloru skóry, wyznania czy narodowości" 37 . Nierelatywne pojęcie sprawiedliwości nie mogło wywodzić się z przemijających form ekonomicznych, ale mimo wszystko mogło być pojmowane jako część ogólnej prawdy historycznej. Ta prawda historyczna wyrażała się u Marksa nadejściem takiego systemu, w którym wszelkie sprzeczności zostałyby w końcu raz na zawsze przezwyciężone: komunizm. W komunizmie ciągłe zmiany bazy nie byłyby już potrzebne. Tym samym zakończyłyby się również zmiany w nadbudowie, czyli w zakresie idei. Ukształtowanie się takich stosunków produkcji, które nie ulegałyby już dynamice zmiany dziejowej oznaczałoby powstanie realnej bazy dla niezmiennych, czyli nierelatywnych treści myślowych - także idei sprawiedliwości. Taka idea pozostałaby co prawda wciąż wtórna do bazy, w tym wypadku bazy komunistycznej, ale odzwierciedlając niezmienną formę ekonomiczną sprawiedliwość komunistyczna przestałaby być ideą relatywną. Wszelkie idee wywodzące się z systemu komunistycznego wyrażałyby jakościowo nową i absolutną kondycję życia społecznego. Tej nowej jakości systemowej towarzyszyć by musiał zbiór „absolutnych” idei - także „absolutna” idea sprawiedliwości.

36 Por. K. Marks, Krytyka Programu Gotajskiego, wyd. cyt., s. 739-740.

37 Por. K. Marks, Projekt ogólnego statutu i regulaminu administracyjnego Międzynarodowego Stowarzyszenia Robotników zaakceptowany przez Radę Generalna w lecie 1872 r., w: K. Marks, F. Engels, W. Lenin, O sprawiedliwości. Wybór, Warszawa/Moskwa 1986, s. 26-27. 


\section{Absolutna idea sprawiedliwości Marksa}

Wszystkie dotychczasowe „formy ekonomiczne” są według Marksa „przemijające i historyczne" 38 . Tym samym również idee nie są ponadczasowymi kategoriami, lecz stanowią tymczasowe odzwierciedlenia tymczasowych stosunków społecznych opartych na rozwoju gospodarki. Zarzut Marksa zarówno w kierunku burżuazji jak i większości działaczy socjalistycznych polegał na tym, że traktowali oni tymczasowe formy ekonomiczne jako konieczne i naturalne podstawy życia społecznego ${ }^{39}$. Tym samym za „sprawiedliwe” uznane mogło być jedynie to, co mieściło się w ramach systemu. Także te idee sprawiedliwości, których celem miałoby być zreformowanie czy wręcz obalenie systemu, wywodziły się z tegoż właśnie systemu. O ile chcielibyśmy zatem w kontekście twórczości Marksa doszukiwać się sprawiedliwości innej aniżeli tylko relatywnej, to nie możemy próbować uchwycić jej w kategoriach czysto etycznych - albowiem tak właśnie czynili przeciwnicy Marksa, czyli burżuazja oraz „socjalistyczni sekciarze”. Najprościej rzecz ujmując: Marks nie łudził się, jakoby zniewolony umysł mógł wyzwolić społeczeństwo.

Sprawiedliwość wykraczająca poza ograniczenia systemowe musiałaby być samorzutnym wynikiem historycznego przezwyciężenia samej historyczności „form ekonomicznych". Innymi słowy: relatywizm moralny nie może zostać przezwyciężony na poziomie idei, lecz na poziomie materialnych podstaw życia społecznego. Krytyka idei może i powinna służyć temu, aby ludzie uświadomili sobie relatywność i tymczasowość systemu społecznego, w którym przyszło im nieszczęśliwie żyć. To nie etyka, lecz dzieje decydują o sprawiedliwości - idee są derywatami, a nie podmiotami sprawczymi. Wspomniałem już, iż Marks głosił nadejście epoki, w której wewnętrzne sprzeczności systemowe zostałyby raz na zawsze przezwyciężone. Aby zatem przybliżyć się rozumowo do niewyrażonej i nierelatywnej idei sprawiedliwości Marksa, trzeba najpierw rozwinąć absolutność systemu komunistycznego.

Otóż na początku trzeba podkreślić, że choć w myśli Marksowskiej każda idea jest wtórna do stosunków produkcji, to nie każda idea - idąc jego tokiem rozumowania - musiałaby być relatywna. Albowiem o ile wciąż zmieniajace się formy ekonomiczne determinują zmienność idei, o tyle nastanie niezmiennych form ekonomicznych stworzyłoby realną bazę dla powstania niezmiennych treści myślowych. Pytanie o możliwość powstania absolutnych idei, w tym także idei sprawiedliwości, wymaga zatem postawienie pytania o możliwość powstania

38 K. Marks, List do P. Annienkowa, wyd. cyt., s. 767.

39 Tamże, s. $771-772$. 
niezmiennych stosunków produkcji, czyli absolutnego systemu społecznego. Stawiając śmiałą tezę o nieuchronności nadejścia komunizmu Marks implicite zasugerował zatem powstanie absolutnej idei sprawiedliwości społecznej - choć nie dał jej bezpośredniego wyrazu w swoich pismach. Aby bowiem nie popaść w sprzeczność z własnym sposobem myślenia Marks nie mógł niczego konkretnego powiedzieć o absolutnej sprawiedliwości systemu komunistycznego: aby bowiem takowa idea w ogóle mogła powstać, musiałaby się najpierw wykształcić realna baza w postaci absolutnego systemu, którą idea ta by odzwierciedlała. Ponadto byłaby to idea jakościowo różna od wszystkich poprzednich idei sprawiedliwości będących jedynie odbiciem walk klasowych, których w społeczeństwie komunistycznym już z definicji by nie mogło być. Skoro więc Marks nie mógł pisać niczego konkretnego o absolutnej sprawiedliwości komunizmu, jesteśmy zmuszeni wydedukować tą absolutną sprawiedliwość poprzez próbę jakościowego odróżnienia komunizmu od wszystkich innych dotychczasowych systemów. Musimy zapytać: w jakim sensie komunizm miałby stanowić jakościowo nową i przez to nieporównywalną do innych systemów formę uspołecznienia?

Otóż struktura dziejów w myśli Marksa dzieli się z grubsza na trzy etapy: harmonię wspólnoty pierwotnej, etap alienacji oraz etap komunizmu. Na początku było społeczeństwo pierwotne, które nie znało jeszcze własności prywatnej w rozumieniu kapitalistycznym. Tę harmonijną kondycję życia zbiorowego cechowała jednakże poważna słabość: nie dostarczała ani jednostce ani społeczności możliwości wszechstronnej i twórczej realizacji. Rozwój jestestwa i życia zbiorowego był bardzo jednostronny, gdyż odpowiadał bardzo prostemu sposobowi życia, który nie wymagał żadnego rozwinięcia podziału pracy ${ }^{40}$. Aby to pierwotne, naturalne skrępowanie potencjału ludzkiego móc przezwyciężyć, wspólnota pierwotna była zmuszona do dezintegracji swojej apriorycznej harmonii. Musiało dojść do wyobcowania, albowiem tylko zachwianie błogiego i zarazem ograniczonego stanu naturalnego mogło jednostce pozwolić na rozwój sił wytwórczych, których miernikiem jest stopień podziału pracy ${ }^{41}$. Kolejnym, drugim etapem dziejów jest okres alienacji. Mieszczą się tutaj wszystkie formacje społeczno-ekonomiczne od antycznej aż do kapitalistycznej formy produkcji. Jest to stan antropologicznego wykorzenienia, ale także koniecznego postępu cywilizacyjnego. Samo pojęcie „alienacji” miało już swoją historię nim Marks użył je dla własnych potrzeb badawczych ${ }^{42}$. Posługiwał się on tym pojęciem w podobny sposób jak Ludwig Feuerbach przy swojej krytyce religii: oddając się pod władzę wyimaginowanej idei Boga, człowiek wyobcowuje się ze swoich realnych zdolności. Tym samym idea Boga została

40 Por. R. Dahrendorf, dz. cyt., s. 76, 78.

41 K. Marks, Ideologia niemiecka, wyd. cyt., 237.

42 Por. R. Dahrendorf, dz. cyt., s. 79. 
przez Lewicę Heglowską zrozumiana jako szyfr i personalizację nierealizowanego potencjału podmiotu ludzkiego. Całe swoje człowieczeństwo człowiek oddał Bogu, aby samemu pozostać marnym śladem swoich autentycznych możliwości. Marks tę Feuerbachowską krytykę religii rozszerzył na wszystkie idee oraz na sam proces pracy, czyli każdej formie produkcji, w której ludzie poddają się w sposób niewolniczy swoim własnym (duchowym bądź materialnym) wytworom. Alienacja to według Marksa najkrócej rzecz ujmując nic innego jak bałwochwalcza władza produktów nad producentem. Istotne cechy alienacji stosunków społecznych to: podział pracy, produkcja towarów i własność prywatna ${ }^{43}$. Wszystkie te aspekty są ze sobą ściśle powiązane i tworzą przez to całościowy system współzależności. Nie można zlikwidować jednego elementu (np. własności prywatnej, jak naiwnie według Marksa marzył Proudhon) nie narażając przy tym całego systemu na niewłaściwe funkcjonowanie, czyli na niesprawiedliwość rozumianą w sensie relatywnym. W odróżnieniu od innych socjalistów Marks nie pragnął poprawy kondycji robotników na gruncie panującego systemu kapitalistycznego. Był on bowiem przekonany, że właśnie sprawne funkcjonowanie systemu kapitalistycznego doprowadzi do sprzeczności i konfliktów, które w ostatecznym rozrachunku doprowadzą do radykalnej i jakościowej zmiany społecznej - do przezwyciężenia systemu jako takiego.

Trzecim i ostatnim etapem rozwoju dziejów byłby zdaniem Marksa komunizm. Byłby to system, który zrywa z wszelką formą alienacji. Jak stwierdza Leszek Kołakowski: „Zniesienie alienacji jest tym samym co komunizm. Jest to totalna transformacja bytu" 44. Aby jednak wyobcowanie zostało bezpowrotnie obalone musi się ono najpierw, po pierwsze, stać siłą „nie do wytrzymania”, czyli „siłą, przeciw której robi się rewolucje”, oraz, po drugie, musi ono stać „w sprzeczności z istniejącym światem bogactwa i wykształcenia" 45 . Podobnie jak „z próżnego nawet Salomon nie naleje”, tak również społeczeństwo musi najpierw wykształcić w sobie aprioryczne warunki materialne, aby móc przekształcić się w system pozbawiony wewnętrznych sprzeczności, w system absolutny - komunistyczny. Te aprioryczne warunki nie mogą jednak zostać inaczej osiągnięte jak poprzez rozwój sił wytwórczych, czyli poprzez rozwój kapitalizmu. Innymi słowy: to, co sprawiedliwe w sensie relatywnym, czyli całe funkcjonowanie społeczeństwa według wyobcowanych zasad życia, musi zostać doprowadzone do ostatecznej perfekcji, aby przeistoczyć się w stan sprawiedliwości absolutnej. Nadejście tego systemu nie może być według Marksa wynikiem etycznego buntu wyzyskiwanych,

\footnotetext{
43 Por. tamże, s. 80.

44 L. Kołakowski, Gtówne nurty marksizmu. 1, Warszawa 2010, s. 176.

45 K. Marks, Ideologia niemiecka, wyd. cyt., s. 256.
} 
lecz wynikiem samego ruchu dziejowego. Albowiem jeśli materialne warunki społeczne nie zostaną wykształcone, nie dojdzie do przewrotu społecznego - nawet jeśli „idea tego przewrotu” byłaby „już sto razy wypowiadana” 46.

Powszechnie znana definicja komunizmu opiera się na uspołecznieniu środków produkcji. Albowiem, jak przekonuje Marks, tylko „przy takim stanie rzeczy, gdzie nie będzie już więcej klas i antagonizmu klasowego, ewolucje społeczne przestaną być rewolucjami politycznymi" ${ }^{47}$. Ale taka definicja sama z siebie jeszcze nie tłumaczy, dlaczego akurat takie rozwiązanie systemowe miałoby oznaczać kres dynamiki dziejowej. Aby zauważyć głębsze, tzn. aksjologiczne przesłanie Marksa, warto podkreślić, że to właśnie w systemie komunistycznym miałoby dojść do ponownego scalenia dwóch aspektów poprzednich etapów dziejowych: wspólnotowości z rozwojem indywidualności. Komunizm nie tylko nie odbiera człowiekowi jednostkowości, ale właśnie „dopiero umożliwia właściwe użytkowanie możności człowieka" ${ }^{48}$. Podkreślmy tutaj, że Marks nie usiłował udowodnić, że uspołecznienie środków produkcji jest bardziej sprawiedliwe niż prywatyzacja środków produkcji - próbował on wskazać, że tylko taki system może rozwiązać najbardziej podstawowy problem nowoczesności: kryzys integracji społecznej. Komunizm nie stanowił dla Marksa idei, której przeciwstawiałby on faktyczną kondycję życia społecznego i która teoretycznie mogłaby już zostać wymyślona w innej epoce aniżeli w epoce nowoczesnej. Wprost przeciwnie, dla Marksa komunizm jest zarazem wytworem jak i odpowiedzią dla nowoczesnego kryzysu uspołecznienia. Nie jest przecież tajemnicą, że to właśnie rozwiązanie tego kryzysu integracji było główną przyczyną powstania naukowej myśli społecznej, czyli socjologii. Nieważne czy czytamy pisma Augusta Comte'a, Emila Durkheima, Maxa Webera, Georga Simmla czy Ferdinanda Tönnisa - wszędzie znajdujemy ten sam problem badawczy: jak zharmonizować życie społeczne zindywidualizowanych jednostek? Myśl socjologiczna wzięła się ze świadomości tegoż właśnie kryzysu nowoczesności. Marksowska teza o konieczności nadejścia systemu komunistycznego jest jednym z wielu sposobów odpowiedzi na ten kryzys - być może najbardziej radykalną z możliwych. Na czym polega ten ,absolutny” radykalizm komunizmu? I jaka „absolutna” idea sprawiedliwości zarówno mu odpowiada jak i towarzyszy?

Otóż Marks był przekonany, że tylko ludzka praca (jako część „siły przyrody”) może być źródłem powstania i tworzenia wartości. Konsekwentnie odmawiał on kapitałowi oraz ziemi zdolności do tworzenia wartości. Tylko taki system, w którym człowiek posiadałby dokładnie tyle ile wypracował, mógłby zostać uznany

\footnotetext{
46 Tamże, s. 263.

47 K. Marks, Nędza filozofii. Odpowiedź na „Filozofię nędzy” P. Proudhona, Warszawa 1949, s. 179 .

48 L. Kołakowski, dz. cyt., s. 176.
} 
za system w pełni sprawiedliwy - za sprawiedliwy w sensie absolutnym. Problem w tym, że takiego systemu jeszcze w dziejach ludzkości nie było, albowiem wszystkie społeczeństwa były społeczeństwami klasowymi, w których jedna klasa korzystała z dóbr wypracowanych przez drugą. Innymi słowy: we wszystkich dotychczasowych formacjach społeczno-gospodarczych normą był i nadal jest taki stan rzeczy, w którym jedni korzystają z dóbr, których sami nie wyprodukowali, a drudzy na odwrót nie mają dostępu do wypracowanych przez siebie wartości. Od czasów antycznych aż do nowoczesności człowiek nauczył się zatem żyć w systemach, które uniemożliwiajac mu zarówno posiadać jak i w pełni korzystać z dorobku własnej pracy ${ }^{49}$. Na dodatek nowoczesny podział tejże pracy sprawia, że człowiek nadal nie realizuje się w sposób wszechstronny, lecz pozostaje ograniczony do mniej lub bardziej wąskiej działalności. Tym samym i wyroby tejże wyspecjalizowanej i wąskiej działalności są zewnętrzne wobec samego wytwórcy i (niczym bożki) panują nad nim i jego życiem. Komunizm odwróciłby ten stan rzeczy o całe sto osiemdziesiąt stopni. Społeczeństwo komunistyczne różni się od wszystkich innych społeczeństw jakościowo pod dwoma względami: zaniknięciem klas oraz osiągnięciem nieograniczonej wydajności środków produkcji. Warto zaznaczyć, iż nieograniczona wydajność środków produkcji nie byłaby zdaniem Marksa natychmiastowym efektem likwidacji kapitału, ale dopiero w późniejszej fazie rozwoju komunizm utorowałby drogę do pełnego rozwoju ludzkiej twórczości. Nastanie ery powszechnego nadmiaru w sposób ostateczny rozwiązałoby kwestię sprawiedliwości: albowiem gdzie nie panuje już niedostatek, tam też trudno o konflikty dotyczące dystrybucji dóbr ${ }^{50}$. Aby jednak system nie popadał w sprzeczność (która jest warunkiem wszelkiej zmiany społecznej i dowodem relatywności systemu), zniesiony musiałby zostać także podział pracy ${ }^{51}$. Przezwyciężenie podziału pracy korelowałoby z kolei z wykształceniem się nie tylko wolnych i twórczych, ale

49 Powiada się, że dwudziestowieczne zmiany strukturalne społeczeństw zachodnich (rozrost klasy średniej, ukształtowanie się zawodu menedżerskiego, sektora usług itd.) obaliły dychotomiczną wizję Marksa. Trudno się jednak w pełni zgodzić z takim stwierdzeniem. Zmiany społeczne XX wieku są co prawda doniosłe dla socjologicznej analizy struktury społecznej, ale nie do końca obalają formalną słuszność tezy Marksa. Nawet gdyby się jeszcze namnożyło kolejnych kilkanaście warstw społecznych, to nadal możemy w duchu myśli Marksa rozróżnić między tymi aktorami społecznymi, którzy nie wytwarzają żadnych dóbr i żyją wartościami cudzej pracy, a tymi, którzy nie mają dostępu do wyprodukowanych przez siebie dóbr. Przekładając myśl Marksa na język współczesny możemy powiedzieć, że mniej istotna jest kwestia kto posiada środki produkcji na własność aniżeli pytanie, kto nad środkami produkcji (współcześnie także ośrodkami informacji - ale to przecież także produkt) posiada realną władzę, którą współczesne teorie społeczne w myśli Michela Foucaulta traktują raczej jak siłę twórczą aniżeli represywną. Niemniej jednym z ważnych wyznaczników naszego systemu społecznego pozostaje wyzysk, który jest zgodny z systemem i jako taki pozostaje czymś sprawiedliwym - oczywiście jedynie w sensie relatywnym.

50 T. Ebert, dz. cyt., s. 176.

51 K. Marks, Ideologia niemiecka, wyd. cyt., s. 253. 
także wszechstronnie uzdolnionych indywiduów. Marks przekonywał, że w społeczeństwie komunistycznym nikt nie ma „wyłącznego kręgu działania, lecz może się wykształcić w jakiejkolwiek dowolnej gałęzi działalności” 52. Albowiem gdy „społeczeństwo reguluje produkcje”, umożliwia ono człowiekowi „robienie dziś tego, a jutro owego", czyli robienie tego, na co dana jednostka "ma akurat ochotę" 53 . O ile z całą słusznością należy nazwać tę wizję na wskroś utopijną, o tyle warto także podkreślić spójność tej myśli Marksa: w odróżnieniu od innych utopii, utopia Marksowska nie legitymizuje się propozycją „lepszej”, czyli bardziej sprawiedliwej organizacji relacji społecznych - legitymizuje się ona tylko i wyłącznie swoja „funkcją w ciągu dziejów” 54. Sprawiedliwość absolutna jest zdaniem Marksa tendencją samych dziejów - a nie abstrakcyjnym pojęciem wynikającym z racjonalnej refleksji jednostek: „Komunizm jest dla nas nie stanem, który należy wprowadzić, nie ideałem, którym miałaby się kierować rzeczywistość. My nazywamy komunizmem rzeczywisty ruch, który znosi stan obecny" 55.

Możemy więc wydedukować kilka podstawowych cech absolutnej sprawiedliwości w myśli Marksa. Po pierwsze, jest ona scentralizowana wokół pracy ludzkiej: sprawiedliwy w sensie nierelatywnym jest tylko taki porządek społeczny, w którym jednostka może się wszechstronnie rozwijać i twórczo realizować. Ponadto jednostka powinna móc w pełni korzystać z wyprodukowanych przez siebie dóbr i wartości - co z kolei oznacza, że w systemie komunistycznym nie byłoby miejsca na wartość dodatkową, która generuje kapitał poprzez wyzysk pracy najemnej. Po drugie sprawiedliwość absolutna jest skoncentrowana na zbiorowości - a nie na jednostce. Nie chodziło Marksowi o to, aby polepszyć kondycję ekonomiczną poszczególnych jednostek albo całej klasy, ale o to, aby system, czyli sposób produkcji, w sposób adekwatny odpowiadał ludzkim potrzebom i możliwościom ${ }^{56}$. Te dwie cechy zostają jeszcze dopełnione przez trzeci, kluczowy wymiar jego dzieła: perspektywę rewolucyjną ${ }^{57}$. Nowoczesna świadomość kryzysu oczekiwała jakiegoś przełomu, kairos, który raz na zawsze obróciłby losy ludzkości i świata na właściwy tor. I choć każda zmiana formacji społeczno-gospodarczej była zdaniem Marksa rewolucyjna, to rewolucja komunistyczna miałaby być tą jakościowo inną rewolucją, która daje kres wszystkim rewolucjom jako takim. Albowiem dotychczas rewolucje zmieniały tylko jedną relatywną formę bazę (wraz

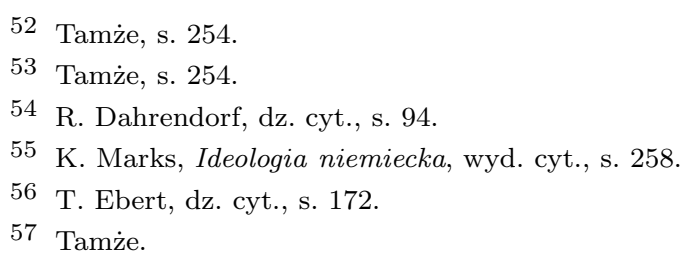


z nadbudową) na inną - także relatywną i przez to w końcu przemijajaccą. Rewolucja komunistyczna zmieniłaby jednak relatywne porządki społeczne na ostateczny porządek absolutny i konieczny. Sprawiedliwość społeczeństwa komunistycznego polegałaby na tym, że społeczeństwo to byłoby „związkiem wolnych ludzi” „prawdziwą wspólnotą", jak w stanie naturalnym, w którym jednostki na poziomie indywidualnym wszechstronnie się realizują. Zniesienie podziału pracy byłoby naturalnym efektem takiego rozwoju społecznego ${ }^{58}$.

Przesłanie Marksa wydaje się być zatem jasne: zamiast moralizować w imię abstrakcyjnych idei o złagodzeniu wewnętrznych sprzeczności systemowych, absolutna sprawiedliwość polegałaby na tym, aby skorzystać z owoców kapitalizmu i odwrócić ten system przeciwko jemu samemu. Najkrócej i najprościej rzecz ujmując: sprawiedliwym w sensie absolutnym jest absolutna rewolucja, czyli totalna transformacja bytu. Owa transformacja nie potrzebuje zgodnie z myślą Marksa żadnej ideowej otoczki albo legitymizacji, albowiem wynika ona z samych dziejów, czyli z samej działalności człowieka - tego rzeczywistego i pracującego człowieka, który „stacza wszystkie walki” ${ }^{59}$. Sprawiedliwość już się dokonała poprzez rozwój takich sił wytwórczych, dzięki którym moglibyśmy stworzyć nowy porządek społeczny - porządek, w którym życie ludzkie przestałoby stanowić wyobcowaną praktykę. Trzeba by tej potencjalnej sile tylko oddać sprawiedliwość w postaci stworzenia nowych parametrów jestestwa. Na tym zakończyłaby się ostatecznie historia sprawiedliwości. I właśnie ten koniec sprawiedliwości relatywnej byłby zgodnie z myślą Marksa sprawiedliwy - w sensie absolutnym.

\section{Zamiast wniosków - próba krytycznej refleksji i pytania}

Katastrofy związane z reżimami totalitarnymi XX wieku spowodowały, że twórczość Marksa pozostawia swoich odbiorców w niezwykle trudnej sytuacji tak trudnej, że znaczna część świata akademickiego zdecydowała się w dużym stopniu ignorować jego dzieło, co z kolei powoduje, iż po upadku realnego socjalizmu żadna fundamentalna krytyka systemu kapitalistycznego nie jest już brana pod uwagę. Pozostaje dość przerażająca wizja pozostałych współczesnych marksistów, jakoby Marks sformułował dobrą ideę, która została źle wykonana - co z kolei implikuje gotowość do ponownej „próby”. Powyższa próba wydedukowania z twórczości Marksa jakiegoś aksjologicznego centrum w postaci absolutnej

58 R. Dahrendorf, dz. cyt., s. 101.

59 L. Kołakowski, dz. cyt., s. 144. 
idei sprawiedliwości bynajmniej nie rozwiązuje fundamentalnej trudności związanej z jego myślą i jej konsekwencjami. Niemniej może ona odtworzyć nowe, niemarksistowskie możliwości interpretacji twórczości Marksa. Z jednej strony przedstawia on kapitalistyczną rzeczywistość społeczną jako sferę nieustającego wyzysku - z drugiej strony wskazuje, że nie można owej kapitalistycznej rzeczywistości społecznej odmówić „sprawiedliwości”, gdyż owa idea wyraża jedynie na poziomie relatywnym zgodność indywidualnych działań z całościowym funkcjonowaniem systemu. Najkrócej rzecz ujmując: z funkcjonalnego punktu widzenia systemu kapitalistycznego wyzysk i alienacja są jak najbardziej - sprawiedliwe. Nie ma zdaniem Marksa sensu przeciwstawiać się jej za pomocą kolejnych idei, które w ramach kapitalizmu byłyby jedynie „czystymi myślami” - myślami pozbawionymi instytucjonalnego zakorzenienia. Narzuca się więc pytanie: Skoro nie możemy systemowi skutecznie przeciwstawić alternatywnych idei sprawiedliwości - to co pozostaje z idei stworzenia (bardziej) sprawiedliwego społeczeństwa?

Analizując i interpretując myśl Marksa z punktu widzenia XXI wieku, można być skłonnym uznać ją za „kolejną” utopię, kolejną meta-narracje, która w dobie ponowoczesności nie ma już racji bytu. Można wręcz zwrócić myśl Marksa przeciwko jej samej: skoro nie nastała na poziomie systemowym era ostatecznego przezwyciężenia alienacji, to samą twórczość Marksa należałoby także nazwać „czystą myślą" - idea pozbawioną realnego odniesienia do faktycznych stosunków społecznych. Choć taki zarzut nie byłby pozbawiony racji, chciałbym jednak zaryzykować polemikę z takim podejściem do twórczości Marksa.

Niewątpliwie dzieło Marksa bywa nieprzypadkowo, aczkolwiek wbrew jego własnym intencjom, zaliczane do myślenia utopijnego. Można podejrzewać, iż podobnie jak w przypadku Émile'a Durkheima i Ericha Fromma - bogata tradycja rabinacka w rodzinie Marksa odegrała znaczacy wpływ na jego własny sposób myślenia i proroczy sposób ujmowania dziejów ${ }^{60}$. Kluczową przesłanką judaizmu „jest radykalne przeciwstawienie bytu i powinności: tego, co istnieje i tego, co być powinno - marnego świata doczesnego i doskonałego ładu Bożego" 61. Aksjologiczna podstawa dla utopijnego myślenia w żydowskiej tradycji myślowej stanowi fundamentalny rozziew między „sferą faktyczności” a „sferą zobowiązania”. Niemniej trzeba w tym miejscu podkreślić, że wczytując się w prorockie księgi judaizmu nie dowiadujemy się przecież, jak być powinno - ale jak (rzekomo) będzie. Ruchy dziejów nie są ukierunkowane przez normy, tylko przez wolę Boga, która przynajmniej z tego punktu widzenia stanowi konieczność dziejową. Dla-

60 Por. H.Monz, Gerechtigkeit bei Karls Marx und der hebräischen Bibel. Übereinstimmung, Fortführung, und zeitgenössische Identifikation, Baden-Baden 1995.

61 Por. A. Flis, Chrześcijaństwo a Europa. Studia z dziejów cywilizacji Zachodu, Kraków 2003, s. 416,422 . 
tego paradoksalnie właśnie faktyczna warstwa dziejowa, przepełniona złem, różnorakimi krzywdami i niesprawiedliwością, prowadzi ostatecznie wybrany lud do Królestwa Bożego ${ }^{62}$. Ta myśl stanowi także istotę chrześcijańskiej eschatologii: wina za grzechy staje się poprzez oraz wraz z Odkupieniem „winą szczęśliwą” (felix culpa), gdyż otwiera drogę dla manifestacji nieograniczonego miłosierdzia Bożego - miłosierdzie uosobiono w postaci cierpiącego Chrystusa. Paradoksalnie zatem z punktu widzenia narracji judeochrześcijańskiej odrzucenie Boga toruje człowiekowi drogę do poznania Jego łaski. W ateistycznej myśli Marksa jest analogicznie: alienacja wydaje się być złem, ale bynajmniej nie stanowi zła nikczemnego - jest ono złem zarówno koniecznym, jak i w pewnym sensie zbawczym. W odróżnieniu od innych socjalistów Marks nie dostrzegał „w nędzy tylko nędzy", ale także „stronę rewolucyjną, burzącą, która obali stare społeczeństwo" 63. Albowiem wraz z potęgowaniem skutków alienacji równocześnie wykształcone zostają te siły i stosunki produkcji, które umożliwiają w końcu ostateczne zniesienie wszelkiej alienacji. Można przypuszczać, że fascynacja myślą Marksowską w XIX i XX wieku miała wiele wspólnego z tym, że w dobie nowoczesnego rozwoju oświecenia, industrializacji, liberalizacji, demokratyzacji i osłabienia roli chrześcijaństwa dla integracji społecznej, to właśnie myśl Marksa najwierniej zachowała „historyzm żydowski”, który „był stale obecny w kulturze europejskiej od czasów Reformacji" 64 .

Związek między myślą Marksa a żydowską tradycją myślową w sposób dobitny wyraził wspomniany już Erich Fromm: według niego teoria alienacji Marksa wzoruje się na biblijnym zakazie bałwochwalstwa. Zamiast wielbić i poddawać się swoim własnym produktom człowiek jest zobowiązany wielbić tylko $i$ wyłacznie jedną jedyną siłę twórczą (produktywną) - Boga. Albowiem tylko „On” nie jest wytworem ludzkim - tylko „On” nie jest „bożkiem” 65. Jedną z podstaw myśli Marksowskiej stanowi według Fromma prorockie przesłanie, że „prawda” nas wyzwoli od wszelkich form wyobcowania, zarówno w wymiarze indywidualnym, jak i społecznym ${ }^{66}$. Ta „prawda” w niniejszym kontekście byłaby stanem absolutnej sprawiedliwości społecznej, czyli takiej kondycji życia zbiorowego, w którym sama problematyka sprawiedliwości zostałaby bezpowrotnie przezwyciężona. W ten sposób staje się zrozumiałe, dlaczego Marks w żadnym miejscu nie nazywa

\footnotetext{
62 Tamże, s. 419.

63 Por. K. Marks, List do redakcji pisma „Sozialdemokrat” (do J. B. Schweitzera), w: tenże, Nędza filozofii..., wyd. cyt., s. 41.

64 A. Flis, dz. cyt., s. 447.

65 Por. E. Fromm, Das Menschenbild bei Marx, Frankfurt am Main 1969, s. 49.

66 Por. E. Fromm, Zerwać okowy iluzji. Moje spotkanie z myśla Marksa i Freuda, przeł. J. Karłowski, Poznań 2000, s. 32.
} 
społeczeństwa komunistycznego społeczeństwem „sprawiedliwym”: jest to porządek mieszczący się na poziomie aksjologicznym poza wszelką dotychczasową ideą sprawiedliwości bądź niesprawiedliwości w rozumieniem relatywnym, czyli jako zgodności z systemem. Wszystkie dotychczasowe formy ekonomiczne bazowały na sprzecznościach, co powodowało problematykę określenia „sprawiedliwego” podziału dóbr i pracy. Ta problematyka jednak znika w obliczu nastania systemu pozbawionego sprzeczności - systemu absolutnego. W komunizmie z definicji nie byłoby miejsca dla fundamentalnego rozdziału między byciem a powinnością, gdyż horyzont marzeń i oczekiwań zostałby tym samym zrealizowany w realnym życiu społecznym.

Ale jak zrealizować marzenia bez idei? Czy zmiana rzeczywistości nie wymaga transgresji tejże rzeczywistości na poziomie metafizycznym? Skoro z punktu widzenia XXI wieku już wiemy, że dzieje nie doprowadziły do stanu absolutnej sprawiedliwości społecznej, to w jaki sposób i w imię czego mielibyśmy się współcześnie przeciwstawiać systemowi? Czy odrzucenie Marksa, niczym fałszywego proroka, oznaczałoby, że musimy wrócić do „frazesów” o sprawiedliwości jako szlachetnej idei, która jednak nie może wyjść poza fundamentalne zasady funkcjonowania systemu opartego na wyzysku siły roboczej? Czy mielibyśmy pogodzić się z relatywizmem i w jego obrębie szukać mniejszych narracji o moralno-etycznym charakterze i przesłaniu? Czy jesteśmy zatem skazani na sprawiedliwość względną, na zgodność z systemem, na reformy zmierzające jedynie do zwiększenia obywatelskiego konformizmu? Czy socjalizacja społeczna miałaby docelowo służyć temu, aby człowiek godził się na narzucone mu wzory uspołecznienia?

Chciałbym w tym miejscu zacytować słowa Bogdana Suchodolskiego: „Stanowisko zajęte przez Marksa i Engelsa oznacza, iż wychowanie powinno sięgać głębiej niż to w burżuazyjnej pedagogice przyjmowano. Powinno sięgać do tej warstwy życia, w której kształtuje się realny sposób istnienia jednostki, a nie poprzestawać na tej, w której przedstawia ona sama sobie to, jaka - rzekomo - jest" 67 . Innymi słowy: człowiek powinien być istotą zdolną do krytyki realnych sposobów życia społecznego. Nie powinien tego jednak czynić na poziomie idei, lecz powinien, jak przekonuje Suchodolski, wejść „głębiej”, tzn. odkryć prawdziwe funkcjonowanie systemu. I co tam odnajdzie? Wydaje mi się, że człowiek zdolny do fundamentalnej krytyki systemu zauważy nie tylko realne sprzeczności systemu, ale także - jego realne możliwości. Te możliwości systemu mogą się człowiekowi jawić jako abstrakcyjne idee, czyste myśli, utopie - ale na tym właśnie mogłaby polegać czujność współczesnego człowieka, żeby potrafił odróżnić te idee, które są jedynie czystymi myślami, od tych, które wyrażają realne możliwości systemu, które

67 B. Suchodolski, Wstęp, w: K. Marks, F. Engels, O wychowaniu, wybrał i wstępem opatrzył B. Suchodolski, Wrocław-Warszawa-Kraków 1965, s. XVII. 
nie zostały, aczkolwiek mogłyby zostać zrealizowane w tymże systemie. Czy sam system uległby przez to fundamentalnej zmianie, jak przekonywał Marks, jest już innym pytaniem.

Kluczem do zrozumienia „absolutnej” idei sprawiedliwości Marksa jest to, że nie jest ona jedynie teorią, lecz rewolucyjną praktyką społeczną. Na tym polega zarówno jej wyjątkowość, ale także jej wątpliwy charyzmat akcjonizmu toczącego się w imię konieczności dziejowej. W momencie gdy to człowiek - a nie Bóg, jak $\mathrm{w}$ tradycji prorockiej - staje się w swoim własnym mniemaniu podmiotem tej konieczności, dzieje muszą wynikać z działania ludzkiego. Człowiek wierzący w taką opcję stoi przed trudnym zadaniem, albowiem z całokształtu myśli Marksa dość jasno wynika, że stan absolutnej sprawiedliwość społecznej jest niezrealizowanym potencjałem systemu kapitalistycznego - a nie jego nadbudową (tym bowiem jest sprawiedliwość relatywna). Fundamentalne zagrożenie polega jednak na tym, że człowiekowi może się mylnie wydawać, żeuzyskał nieomylną wiedzę oraz związaną z tym świadomość bycia podmiotem na poziomie absolutnym. W tym sensie Suchodolski pisze, że „wychowanie powinno angażować ludzi do walki społecznej, dzięki której zmieniane będą warunki i możliwości ich życia" ${ }^{68}$. Niestety owa „walka społeczna” pozostaje niesprecyzowana, a w połączeniu z wiedzą historyczną może wśród wielu współcześnie budzić jedynie zgrozę i odrazę. Dlatego warto jeszcze raz podkreślić, że zgodnie z interpretacją niemarksisty Ralfa Dahrendorfa walka o absolutną sprawiedliwość nie byłaby walką w imię jakiejś idei abstrakcyjnej, lecz walką w imię realnych możliwości samego systemu. Byłaby to walka o pełne, czyli absolutne wykorzystanie potencjału systemu. Tylko taka interpretacja myśli Marksa mogłaby chronić samo społeczeństwo przed ujemnymi konsekwencjami dogmatyzmu marksistowskiego. Wychodząc poza ideologiczne skrzywienia myśli Marksa, warto przypomnieć, iż jego zdaniem w nowoczesności „wszelka rzecz jest jak gdyby brzemienna w swe przeciwieństwa” ${ }^{69}$. Jednak z pewnych przyczyn nawet ponowoczesna rzeczywistość społeczna wciąż nie oddaje sprawiedliwości nawet potencjalnym możliwościom systemu, nie mówiąc już o jego przeciwieństwach. Myśl Marksa implikuje, że znał on takie pojęcie sprawiedliwości, które wychodziłoby ponad relatywną sprawiedliwość systemów polegających na wyobcowanym, nieautentycznym, niewłaściwym jestestwie człowieka. I choć wiele aspektów jego twórczości dotyczących faktycznych fenomenów życia społecznego jak choćby przestarzała teoria obiektywnej wartości towarów, należy współcześnie uznać za nieadekwatne współczesnym zasadom ekonomii i uspołecznienia, to jednak te aspekty jego twórczości, które implikują normatywne i kry-

68 Tamże.

69 K. Marks, Przemówienie wygłoszone na obchodach rocznicy gazety "The People's Paper”, w: K. Marks, F. Engels, O wychowaniu, wyd. cyt., s. 275. 
tyczne podejście do życia społecznego bynajmniej nie tracą na aktualności. Albowiem to właśnie Marks zapytał: na ile faktyczny porządek społeczny pozwala jednostkom korzystać z ich własnego potencjału i zdolności? Czy nie żyjemy w okresie dziejów, w którym nie tylko dystrybucja dóbr, ale same stosunki produkcji mogłyby ulec radykalnej zmianie? Z jakich to przyczyn uważamy, że nasz porządek gospodarczy jest jedynym „naturalnym” porządkiem - sprawiedliwym i zarazem funkcjonalnym?

Przy całej świadomości zagrożenia, jakie niesie ze sobą idea sprawiedliwości ujętej jako rewolucja społeczna, należałoby się przyjrzeć, na ile nasze społeczeństwo jest faktycznie zdolne, aby każdej jednostce zapewnić indywidualny rozwój talentów, umiejętności, zainteresowań. Niezależnie od sympatii bądź antypatii dla myśli Marksa trzeba przyznać, że absolutna idea sprawiedliwości Marksa stawia sprawę bardzo jasno: skoro uzyskaliśmy materialne warunki, aby stworzyć lepszy porządek społeczny, w którym wyzysk i bieda mogłyby zostać przynajmniej zredukowane do minimum i w którym wspólnotowość korelowałaby z wszechstronnym rozwojem indywidualnym - to cóż nas jeszcze hamuje, aby taki absolutnie sprawiedliwy porządek społeczny realizować? Co jeszcze uniemożliwia nam przezwyciężenie tych relatywnych form (nie)sprawiedliwości na rzecz nowych form uspołecznienia, w których absolutna sprawiedliwość byłaby niewyartykułowanym derywatem? Otóż wygląda współcześnie na to, że zamiast twórczo rozwinąć korzyści płynące z cywilizacji zachodniej wolimy paradoksalnie czekać na jego implozję. Im głośniejsze stają się okrzyki na rzecz tolerancji, pluralizmu, otwartości, tym paradoksalnie mniejsze szanse dajemy tymże wartościom na realne ich powstanie i przetrwanie. Wciąż chyba wygodniej mówić i pisać o szlachetnych ideach zamiast stworzyć zarówno materialne jak i intelektualne warunki, które uczyniłyby ze szlachetnych idei szlachetną rzeczywistość społeczną. Współcześnie Marks wydaje się nam mówić: Drzwi stoja szeroko otwarte, ale wy nadal szukacie kluczy.

„Niechaj zrozumie, kto potrafi" 70 ...

\section{The idea of justice in Marx's thought}

\section{Summary}

From the perspective of the history of ideas the output of Karl Marx poses a very difficult object of research. Though Marx himself made the issue of social justice a central aspect of his scientific praxis, the idea of "justice" itself seems to be paradoxically rather insignificant in his work. Nevertheless, no other philosophical conception has initiated such a number of social and

70 K. Marks, Krytyka Programu Gotajskiego, wyd. cyt., s. 23. 
political movements that eagerly tried to overcome the injustice of the capitalistic system and thereby radically change the fundamental processes of sociation. On the basis of the thoughts of non-Marxist Ralf Dahrendorf I will try to show that Marx's conception of historical materialism itself contains two ideas of justice: first a "relative" idea of justice, which Marx criticized for being a functional superstructure of the capitalistic system - and the second is an "absolute" idea of justice, which Marx did not articulate directly but which can be understood on the basis of his work as a target of the social revolution. However, in Marx's work this "absolute" idea of justice is not a utopian one, but it poses a materialistic potential of the capitalistic system that is still waiting for its realization.

Key words: justice, capitalism, exploitation, work, revolution

Słowa kluczowe: sprawiedliwość, kapitalizm, wyzysk, praca, rewolucja

\section{Bibliografia}

Błuszkowski J., Wstęp, (w:) K. Marks, Myśli, pod. red. J. Błuszkowskiego i A. Wajdy, PIW, Warszawa 1978.

Dahrendorf R., Die Idee des Gerechten im Denken von Karl Marx, Verl. Für Literatur und Zeitgeschehen, Hannover 1971.

Ebert T., Soziale Gerechtigkeit. Ideen - Geschichte - Kontroversen, Bundeszentrale für politische Bildung, Bonn 2010.

Flis A., Chrześcijaństwo a Europa. Studia z dziejów cywilizacji Zachodu, Nomos, Kraków 2003.

Fromm E., Das Menschenbild bei Marx, Europäische Verlagsanstalt, Frankfurt am Main 1969.

Fromm E., Zerwać okowy iluzji. Moje spotkanie z myśla Marksa i Freuda, przeł. J. Karłowski, Dom Wydawniczy „Rebis”, Poznań 2000.

Holzleithner E., Gerechtigkeit, Facultas Verlags- und Buchhandels AG, Stuttgart 2009.

Kołakowski L., Główne nurty marksizmu. 1, PWN, Warszawa 2009.

Marks K., Ideologia niemiecka (Fragmenty), (w:) K. Marks, Pisma wybrane. Człowiek $i$ socjalizm, wyboru dokonał i wstępem opatrzył J. Ładyka, PWN, Warszawa 1979 .

Marks K., Krytyka Programu Gotajskiego (Fragmenty), (w:) K. Marks, Pisma wybrane. Człowiek $i$ socjalizm, wyboru dokonał i wstępem opatrzył J. Ładyka, PWN, Warszawa 1979 .

Marks K., List do P. Annienkowa, (w:) K. Marks, Pisma wybrane. Człowiek i socjalizm, wyboru dokonał i wstępem opatrzył J. Ładyka, PWN, Warszawa 1979. 
Marks K., List do redakcji pisma „Sozialdemokrat” (do J. B. Schweitzera), w: K. Marks, Nędza filozofii. Odpowiedź na „Filozofie nędzy”. P. Proudhona, Książka i Wiedza, Warszawa 1949.

Marks K., List Marksa do Pawła Annienkowa w Paryżu, (w:) K. Marks, Pisma wybrane. Człowiek i socjalizm, wyboru dokonał i wstępem opatrzył J. Ładyka, PWN, Warszawa 1979 .

Marks K., Marks do Rugego, (w:) K. Marks, Pisma wybrane. Człowiek i socjalizm, wyboru dokonał i wstępem opatrzył J. Ładyka, PWN, Warszawa 1979.

Marks K., Nędza filozofii. Odpowiedź na „Filozofię nędzy” P. Proudhona, Książka i Wiedza, Warszawa 1949.

Marks K., Projekt ogólnego statutu i regulaminu administracyjnego Międzynarodowego Stowarzyszenia Robotników zaakceptowany przez Radę Generalna w lecie 1872 r., (w:) K. Marks, F. Engels, W. Lenin, O sprawiedliwości. Wybór, Wydawnictwo „Książka i Wiedza” RSW „Prasa-Książka-Ruch”, Warszawa/Moskwa 1986.

Marks K., Przemówienie wygłoszone na obchodach rocznicy gazety „The People's Paper”, (w:) K. Marks, F. Engels, O wychowaniu, wybrał i wstępem opatrzył B. Suchodolski, Zakład Narodowy imienia Ossolińskich. Wydawnictwo Polskiej Akademii Nauk, Wrocław-Warszawa-Kraków 1965.

Marks K., Przyczynek do krytyki Heglowskiej filozofii prawa. Wstęp, (w:) K. Marks, Pisma wybrane. Człowiek $i$ socjalizm, wyboru dokonał i wstępem opatrzył J. Ładyka, PWN, Warszawa 1979.

Monz H., Gerechtigkeit bei Karls Marx und der hebräischen Bibel. Übereinstimmung, Fortführung, und zeitgenössische Identifikation, Nomos Verlagsgesellschaft, Baden-Baden 1995.

Stollberg-Rilinger B., Einleitung. Was heißt Ideengeschichte?, (w:) Ideengeschichte. Basistexte, pod. red. B. Stollberg-Rollinger, Steiner, Stuttgart 2010.

Suchodolski B., Wstep, (w:) K. Marks, F. Engels, O wychowaniu, wybrał i wstępem opatrzył B. Suchodolski, Zakład Narodowy imienia Ossolińskich. Wydawnictwo Polskiej Akademii Nauk, Wrocław-Warszawa-Kraków 1965.

Tetens H., Wittgensteins „Tractatus”. Ein Kommentar, Reclam, Stuttgart 2009.

Wittgenstein L., Tractatuslogico-philosophicus, przeł. B. Wolniewicz, PWN, Kraków 1970.

Markus Lipowicz, doktor nauk społecznych w zakresie socjologii, Akademia Ignatianum w Krakowie, e-mail: markus.lipowicz@onet.eu 
